\author{
ACTA MYCOLOGICA \\ Vol. 46 (2): 223-232 \\ 2011
}

\title{
Revised data on the occurrence of myxomycetes in Central Poland
}

\author{
MARIA ŁAWRYNOWICZ1 ${ }^{1}$, DOMINIKA ŚLUSARCZYK ${ }^{1}$ and AGNIESZKA SALAMAGA²
}

\author{
${ }^{1}$ Department of Mycology, University of Łódź \\ Banacha 12/16, PL-90-237 Łódź, miklaw@biol.uni.lodz.pl \\ ${ }^{2}$ Institute of Botany, Jagiellonian University, Kopernika 27 \\ PL-31-501 Kraków, asalamaga@wp.pl
}

Ławrynowicz M., Ślusarczyk D., Salamaga A.: Revised data on the occurrence of myxomycetes in Central Poland. Acta Mycol. 46 (2): 223-232, 2011.

A checklist of 81 taxa has been prepared on the basis of 750 exsiccates of slime moulds collected in the years 1958-2009 in the area of Central Poland and preserved in the Herbarium LOD F. All these materials were reexamined according to contemporary literature. The paper summarizes the existing data concerning the occurrence of slime moulds in this area. Among the identified taxa there are four species indicated in the red list in Poland: Badhamia affinis, Physarum robustum, Didymium leptotrichum, and Clastoderma debaryanum.

Key words: slime moulds, checklist, biodiversity, distribution

\section{INTRODUCTION}

Slime moulds (Myxomycetes, Mycetozoa) are the group of organisms of increasing importance in biological and phylogenetical respects. Their morphological, ecological and genetic diversity is the matter of interest for specialists worldwide (e.g., Ing 1994; Heilmann-Clausen 2001; Krieglsteiner 2004). In Poland, a vast programme of biodiversity studies has been recently undertaken (Mirek ed. 2002-2009) resulting, among other works, in a checklist of 222 myxomycetes, that includes all hitherto published taxa (Drozdowicz, Ronikier, Stojanowska and Panek 2003). Recently, a field study in NE Poland has brought an interesting and rich collection of slime moulds (Panek, Romański 2010). The above publications stimulated the authors of the present paper to examine and revise slime moulds collections from the area of Central Poland, preserved in the Herbarium Universitatis Lodziensis (LOD F). Until now, some data concerning slime moulds in Central Poland were published by Orzechowski (1966) - from the Łódź city and adjacent areas, Kalinowska-Kucharska (1975) - from several localities in the area including all the myxomycetes collected in the nature reserves in course of mycocoenological studies by Ławrynowicz (1973). At present, a detailed study of slime moulds has 
started in the area of Las Łagiewnicki Forest in Łódź by Salamaga (2011). The present report is a starting point for further studies of myxomycetes in this area. It could be also used for monitoring studies on slime moulds diversity changes in time.

\section{STUDY AREA}

The area of investigations is situated within the administrative borders of Łódź Province (Fig. 1). From the geographical point of view it is an area of transitional character between uplands in south and lowlands in the northern part. Its significant feature is

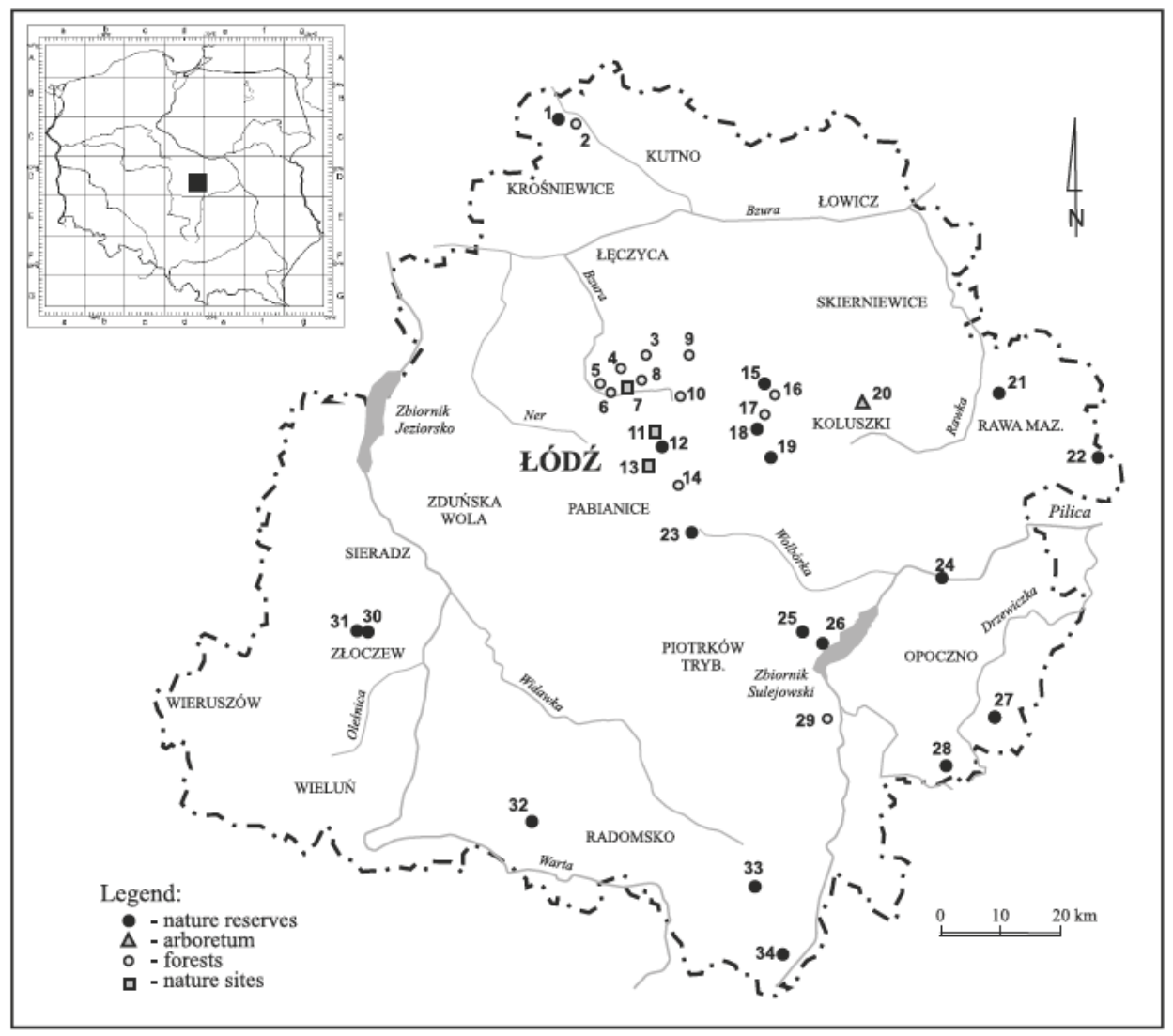

Fig. 1. Localities of the myxomycete records concerned in the paper: $1 . \mathrm{O}-$ Ostrowy; 2. P-Perna; 3. Luć - Lućmierz; 4. Gr - Grotniki; 5. Jas - Jastrzębiec ; 6. Bruż - Brużyca; 7. Nak - Las Nakielnicki; 8. Kr - Krogulec; 9. Sz - Szczawin; 10. LL - Las Łagiewnicki; 11. PLZ - Park Ludowy na Zdrowiu; 12. PK - Polesie Konstantynowskie; 13. Lubl - Lublinek; 14. Rd - Las Rudzki; 15. PJ - Parowy Janinowskie; 16. J-Janinów; 17. Pap-Paprotnia; 18. W-Wiączyń; 19. G-Galków; 20. ArR - the Rogów Arboretum; 21. Ba - Babsk; 22. T - Trębaczew; 23. M - Molenda; 24. S - Spała; 25. Msz - Meszcze; 26. L-Lubiaszów; 27. B - Białaczów; 28. JS - Jodly Sieleckie; 29. Ka - Kalén; 30. NW - Nowa Wieś; 31. K-Komasówka; 32. Mur - Murowaniec; 33. KW - Kobiele Wielkie; 34. D - Dębowiec. 
a watershed between the catchment areas of Warta and Vistula rivers, running from the south to the north and dividing the area into two parts. As a consequence of geological, climatic and hydrological characters, the northern occurrence limits of three important forest trees: Fagus sylvatica, Picea abies and Abies alba run through this area. The most valuable stands of these tree species are protected in nature reserves.

Transitional character of Central Poland creates specific conditions for vegetation cover and communities of different organisms, including slime moulds.

The materials studied come from 34 localities indicated on the map (Fig. 1).

\section{MATERIAL AND METHODS}

In total 750 records of slime mould collected in the period 1958-2009 are the subject of interpretation. The specimens were analyzed using routine microscopic and laboratory techniques. The identification of species was carried out according to specialistic literature, e.g.: Krzemieniewska (1960), Neubert, Nowotny and Baumann (1993, 1995), Neubert et al. (2000), Martin \& Alexopoulus (1969), Ing (1999) and Nannenga-Bremekamp (1991). The nomenclature follows Drozdowicz et al. (2003), updated according to Lado (2005-2011).

Table 1

Correspondence between sources of information (Tab.2) and study areas

\begin{tabular}{|c|c|c|c|c|c|}
\hline & 1 & 2 & 3 & \multicolumn{2}{|c|}{4} \\
\hline I & PK & $\begin{array}{c}\text { D } \\
\text { K } \\
\text { KW } \\
\text { L } \\
\text { M } \\
\text { NW } \\
\text { O } \\
\text { PK } \\
\text { S } \\
\text { T }\end{array}$ & $\begin{array}{l}\mathrm{G} \\
\mathrm{PJ} \\
\mathrm{W}\end{array}$ & $\begin{array}{c}\mathrm{Ba} \\
\mathrm{D} \\
\mathrm{JS} \\
\mathrm{KW} \\
\mathrm{M} \\
\text { Mur } \\
\mathrm{O} \\
\mathrm{PK} \\
\mathrm{T}\end{array}$ & $\begin{array}{c}\text { B } \\
\text { G } \\
\text { K } \\
\text { L } \\
\text { Msz } \\
\text { NW } \\
\text { PJ } \\
\text { S } \\
\text { W }\end{array}$ \\
\hline II & - & - & - & & \\
\hline III & $\begin{array}{c}\text { Bruż } \\
\text { Jas } \\
\mathrm{Kr} \\
\text { Luć } \\
\mathrm{Rd} \\
\mathrm{Sz}\end{array}$ & $\begin{array}{c}\mathrm{Gr} \\
\mathrm{J} \\
\mathrm{Ka} \\
\mathrm{P}\end{array}$ & Рap & $\begin{array}{c}\text { Bruż } \\
\mathrm{J} \\
\mathrm{Ka} \\
\mathrm{LL} \\
\mathrm{P} \\
\mathrm{Rd}\end{array}$ & $\begin{array}{c}\mathrm{Gr} \\
\mathrm{Jas} \\
\mathrm{Kr} \\
\mathrm{Luć} \\
\mathrm{Pap} \\
\mathrm{Sz}\end{array}$ \\
\hline IV & $\begin{array}{l}\text { Lubl } \\
\text { Nak } \\
\text { PLZ }\end{array}$ & - & - & & \\
\hline
\end{tabular}

The columns 1-4 correspond to the sources of information 1-4 included in Table 2. Each of them is divided into four parts corresponding to the four types of study areas: I - nature reserve, II - the arboretum, III - forests, IV - nature sites. 
The detailed register prepared in course of analyzes of all exsiccates (Lawrynowicz, Ślusarczyk and Salamaga 2010) was a basis of synthesis presented in Table 2. The arrangement of taxa is adopted according to Śliwa (2010) and modified for slime moulds. The sources of data (Tab. 2, column 3) are two types: published data (1,2, 3 ) and unpublished data 4 - (numbers of Herbarium exsiccates).

The specimens considered were collected with different intensity and different methods; great part of them were recorded during thorough mycocoenological or other investigations focused on fungi, but some were just single, accidental findings.

The data represent four types of study areas: nature reserves, arboretum, forests, and nature sites (Tab. 1).

All herbarium vouchers are preserved in Herbarium Universitatis Lodziensis (LOD F).

\section{RESULTS AND DISCUSSION}

Macro- and micromorphological analysis of exsiccates of slime moulds preserved in the Herbarium of the Lódź University (LOD F) resulted in the identification of 81 taxa (78 species and 3 varieties). The collection examined contains the records gathered in Central Poland before 2010. The data are summarized in a checklist (Tab. 2). Although the list covers only a number of collecting places and does not provide full information on the occurrence and distribution of slime moulds in the area concerned, it gives several interesting data. Among the slime moulds collected there is a group of widely distributed and frequently noted species: Lycogala epidendrum, Fuligo septica, Ceratiomyxa fruticulosa. There is also a group of rare slime moulds, among them of redlisted species: Badhamia affinis, Physarum robustum, Didymium leptotrichum, and Clastoderma debaryanum (Drozdowicz, Ronikier and Stojanowska 2006). The material examined is not a sufficient basis to describe any species as rare in a broader sense, especially in the case of the taxa observed accidentally at a single locality, but known to be common in other regions. This preliminary checklist indicates that slime moulds can colonize a variety of sites from nature reserves to anthropogenic places.

The first collections of slime moulds in the area of Łódź city and its surroundings (1958-1963) were made by Orzechowski (1966) and reveal the presence of rare species in city parks and small forests. The paper by Kalinowska-Kucharska (1975) indicates that nature reserves are the places hosting the greatest variety of slime moulds. The materials presented in this work were collected during mycocoenological studies in permanent plots in the Tilio-Carpinetum and Potentillo albae-Quercetum associations, in the area of 7 nature reserves: Ostrowy, Molenda, Nowa Wieś, Komasówka, Dębowiec, and Trębaczew.

Other mycocoenological investigations including myxomycetes were conducted in permanent plots in beech forests, mostly in Luzulo pilosae-Fagetum, in the nature reserves Wiączyń, Gałków, and Parowy Janinowskie, as well as in the Paprotnia forest. The reports on slime moulds from that area indicate a great role of dead wood, especially of beech trees, for slime moulds occurrence (Seta, Drozdowicz 2004; Ślusarczyk 
Table 2

Myxomycetes recorded in Central Poland

\begin{tabular}{|c|c|c|}
\hline Name of species & Substrate & Source of information \\
\hline $\begin{array}{l}\text { Amaurochaete atra (Alb. \& } \\
\text { Schwein.) Rostaf. }\end{array}$ & Ps & $1 ; 2$ \\
\hline $\begin{array}{l}\text { A. tubulina (Alb. \& Schwein.) } \\
\text { T. Macbr. }\end{array}$ & $\begin{array}{l}\text { fallen leaves of } B p \\
\text { stump of } P s\end{array}$ & $1 ; 2$ \\
\hline Arcyria affinis Rostaf. & decayed trunk of $F s$ & 2 \\
\hline A. cinerea (Bull.) Pers. & $\begin{array}{l}\text { wood of deciduous } \\
\text { trees }\end{array}$ & $\begin{array}{l}\text { 1; 2; 3; 4: B }(30005,30000,30008) ; \mathrm{JS} \\
(30004)\end{array}$ \\
\hline A. denudata (L.) Wettst. & $\begin{array}{l}\text { wood of deciduous } \\
\text { trees }\end{array}$ & $\begin{array}{l}\text { 1; 2; 3; 4: B (300130); Lubl (30028); LL } \\
(30014,30016) ; \mathrm{Msz}(30022)\end{array}$ \\
\hline A. ferruginea Saut. & $\begin{array}{l}\text { wood of deciduous } \\
\text { trees }\end{array}$ & 1; 2; 4: LL (30032); S (30033) \\
\hline $\begin{array}{l}\text { A. incarnata (Pers. ex J.F. } \\
\text { Gmel.) Pers. }\end{array}$ & $P a, P s$ & 1; 2; 4: B (30038); Lubl (30041) \\
\hline A. obvelata (Oeder) Onsberg & $\begin{array}{l}\text { wood of coniferous } \\
\text { and deciduous trees }\end{array}$ & $\begin{array}{l}\text { 1; 2; 3; 4: ArR (30048); B (30044, 30055, } \\
\text { 30056); JS (30062); LE (30050, 30052, } \\
\text { 30053); Sz (30054) }\end{array}$ \\
\hline A. pomiformis (Leers) Rostaf. & $P a, P s$ & (l) \\
\hline Badhamia affinis Rostaf. & bark of $Q u$ & 2 \\
\hline B. capsulifera (Bull.) Berk. & stump of $A b$ & 2 \\
\hline B. utricularis (Bull.) Berk. & $\begin{array}{l}\text { wood of deciduous } \\
\text { trees; bark of } P s ; \\
\text { twigs of } L a r\end{array}$ & $2 ; 3$ \\
\hline $\begin{array}{l}\text { Ceratiomyxa fruticulosa (O. F. } \\
\text { Müll.) T. Macbr. }\end{array}$ & $\begin{array}{l}\text { wood of deciduous } \\
\text { and coniferous trees }\end{array}$ & $\begin{array}{l}\text { 1; 2; 3; 4: B (30078, 30089); Lubl (30073, } \\
\text { 30076); LE (30072, 30074, 30077, 30092); } \\
\text { S (30071) }\end{array}$ \\
\hline $\begin{array}{l}\text { C. fruticulosa var. porioides } \\
\text { (Alb. \& Schwein.) G. Lister }\end{array}$ & $P a, P s$ & $1 ; 2$ \\
\hline $\begin{array}{l}\text { Clastoderma debaryanum A. } \\
\text { Blytt }\end{array}$ & Ps & 1 \\
\hline $\begin{array}{l}\text { Collaria arcyrionema (Rostaf.) } \\
\text { Nann.-Bremek. ex Lado }\end{array}$ & $\begin{array}{l}\text { wood of deciduous } \\
\text { trees }\end{array}$ & 3; 4: LL (30302) \\
\hline $\begin{array}{l}\text { Comatricha nigra (Pers. ex J. F. } \\
\text { Gmel.) J. Schröt. }\end{array}$ & $\begin{array}{l}\text { fallen branches of } \\
\text { deciduous trees; } F s\end{array}$ & $2 ; 3$ \\
\hline C. pulchella (C. Bab.) Rostaf. & $P a$ & 1 \\
\hline $\begin{array}{l}\text { Craterium leucocephalum (Pers. } \\
\text { ex J. F. Gmel) Ditmar }\end{array}$ & fallen leaves of $Q u$ & 2 \\
\hline Craterium minutum (Leers) Fr. & fallen leaves of $Q u$ & 4: LL (30748) \\
\hline $\begin{array}{l}\text { Cribraria argillacea (Pers. ex J. } \\
\text { F. Gmel.) Pers. }\end{array}$ & $\begin{array}{l}\text { wood of deciduous } \\
\text { trees; } C b, P a, P s\end{array}$ & $1 ; 2 ; 3$ \\
\hline C. aurantiaca Schrad. & Ps & 4: Gr (30126) \\
\hline $\begin{array}{l}\text { C. cancellata (Batsch) Nann.- } \\
\text { Bremek. }\end{array}$ & $\begin{array}{l}\text { wood of coniferous } \\
\text { and deciduous trees }\end{array}$ & $\begin{array}{l}\text { 1; 4: B (30128, 3013, 30135, 30138); JS } \\
\text { (30127); Lubl (30129) }\end{array}$ \\
\hline C. macrocarpa Schrad. & $\begin{array}{l}\text { wood of coniferous } \\
\text { trees }\end{array}$ & 4: B (30749) \\
\hline C. rufa (Roth) Rostaf. & Ps & 2; 4: LL (30143) \\
\hline C. tenella Schrad. & stump of $P S$ & 2 \\
\hline C. vulgaris Schrad. & $P a$ & $1 ; 2$ \\
\hline $\begin{array}{l}\text { Diachea leucopodia (Bull.) } \\
\text { Rostaf. }\end{array}$ & $\begin{array}{l}\text { herbaceous plants; } \\
\text { fallen leaves of } F s\end{array}$ & $2 ; 3 ; 4:$ JS $(30156,30165,30168)$ \\
\hline Diderma radiatum (L.) Morgan & mosses & 4: B (30169) \\
\hline D. spumarioides (Fr.) Fr. & $O a$ & 4: S (30170) \\
\hline D. umbilicatum Pers. & $\begin{array}{l}\text { mosses and fallen } \\
\text { leaves }\end{array}$ & 2 \\
\hline Didymium iridis (Ditmar) Fr. & bark of $F_{s}$ & 1 \\
\hline $\begin{array}{l}\text { D. leptotrichum (Racib.) } \\
\text { Massee }\end{array}$ & $\begin{array}{l}\text { wood of deciduous } \\
\text { trees }\end{array}$ & 4: B (30171) \\
\hline $\begin{array}{l}\text { D. melanospermum (Pers.) T. } \\
\text { Macbr. }\end{array}$ & $\begin{array}{l}\text { mosses; needles } \\
\text { of } P s ; \text { wood of } \\
\text { deciduous trees; } \mathrm{Pa}\end{array}$ & $\begin{array}{l}\text { 1; 2; 3; 4: Lubl (30172) 4: LL (30174); Sz } \\
\text { (30175) }\end{array}$ \\
\hline
\end{tabular}


Table 2 - cont.

\begin{tabular}{|c|c|c|}
\hline D. minus (Lister) Morgan & $\begin{array}{l}\text { stems of herbaceous } \\
\text { plants }\end{array}$ & 2 \\
\hline $\begin{array}{l}\text { D. squamulosum (Alb. \& } \\
\text { Schwein.) Fr. }\end{array}$ & fallen leaves & 2 \\
\hline $\begin{array}{l}\text { Enerthenema papillatum (Pers.) } \\
\text { Rostaf. }\end{array}$ & $\begin{array}{l}\text { wood of deciduous } \\
\text { trees }\end{array}$ & 2 \\
\hline $\begin{array}{l}\text { Fuligo leviderma H.Neubert, } \\
\text { Nowotny \& K. Baumann }\end{array}$ & $B p, F s$ & 3 \\
\hline F. septica (L.) F.H. Wigg. & $\begin{array}{l}\text { wood of deciduous } \\
\text { and coniferous trees; } \\
Q u, P s\end{array}$ & $\begin{array}{l}\text { 2; 3; 4: ArR (30200, 30212); Ba (30210) } \\
\text { B (30208, 30209, 30238); LE (30232 } \\
\text { 30232, 30235, 30236); Msz (30196); Mur } \\
\text { (30222); S (30225); Sz (30233) }\end{array}$ \\
\hline $\begin{array}{l}\text { F. septica var. candida (Pers.) } \\
\text { R.E. Fr. }\end{array}$ & $\begin{array}{l}\text { wood of deciduous } \\
\text { and coniferous trees; } \\
P S\end{array}$ & $\begin{array}{l}\text { 2; 4: ArR (30259); B (30258, 30253); Lubl } \\
\text { (30254); LE (30256, 30257, 30260,); Pap } \\
\text { (30250); W (30252) }\end{array}$ \\
\hline $\begin{array}{l}\text { Hemitrichia clavata (Pers.) } \\
\text { Rostaf. }\end{array}$ & $B p, F s$ & 3; 4: Lubl $(30270,30271) ;$ LE (30268) \\
\hline $\begin{array}{l}\text { H. serpula (Scop.) Rostaf. ex } \\
\text { Lister }\end{array}$ & $A b$ & 4: S (30710) \\
\hline $\begin{array}{l}\text { Lamproderma columbinum } \\
\text { (Pers.) Rostaf. }\end{array}$ & Fs & $1 ; 3$ \\
\hline $\begin{array}{l}\text { Leocarpus fragilis (Dicks.) } \\
\text { Rostaf. }\end{array}$ & $\begin{array}{l}\text { leaves of } Q u ; \text { stems } \\
\text { of } V m ; \text { fern leaves; } \\
\text { bark of } F s ; B p \text { fallen } \\
\text { branches of } Q u, P s\end{array}$ & $\begin{array}{l}\text { 1; 2; 3; 4: ArR (30275); B (30274, 30277, } \\
\text { 30285, 30295); Lubl (30281); LE (30282, } \\
\text { 30288, 30298) }\end{array}$ \\
\hline Lindbladia tubulina Fr. & $\begin{array}{l}\text { wood of deciduous } \\
\text { trees }\end{array}$ & 2 \\
\hline Lycogala conicum Pers. & $\begin{array}{l}\text { wood of coniferous } \\
\text { trees; } Q u\end{array}$ & 1; 4: B (30306) \\
\hline L. epidendrum (L.) Fr. & $\begin{array}{l}\text { wood of deciduous } \\
\text { and coniferous trees; } \\
F s, B p, P s\end{array}$ & $\begin{array}{l}\text { 1; 2; 3; 4: Ba (30376); B (30359, 30395); } \\
\text { J (30371); JS (30396); L (30386); Lubl } \\
\text { (30341); LE (30352, 30353, 30354, 30382, } \\
\text { 30387, 30388, 30397); Msz (30356); Mur } \\
\text { (30343); S (30364, 30379, 30399); Sz } \\
\text { (30366) }\end{array}$ \\
\hline L. exiguum Morgan & Ps & 1 \\
\hline $\begin{array}{l}\text { L. flavofuscum (Ehrenb.) } \\
\text { Rostaf. }\end{array}$ & $\begin{array}{l}\text { wood of deciduous } \\
\text { and coniferous trees }\end{array}$ & 4: LE (30430) \\
\hline $\begin{array}{l}\text { Metarichia floriformis } \\
\text { (Schwein.) Nann.-Bremek. }\end{array}$ & Lar & 4: LL (30435) \\
\hline $\begin{array}{l}\text { M. vesparia (Batsch) Nann.- } \\
\text { Bremek. ex G.W. Martin } \\
\text { \& Alexop. }\end{array}$ & $\begin{array}{l}B p, P s ; \text { wood of } \\
\text { deciduous trees }\end{array}$ & $\begin{array}{l}\text { 1; 2; 3; 4: B (30686, 30692); Lubl (30691); } \\
\text { LE (30690) }\end{array}$ \\
\hline Mucilago crustacea F.H. Wigg. & $\begin{array}{l}\text { grasses; fallen leaves } \\
\text { of } Q u\end{array}$ & $1 ; 2$ \\
\hline $\begin{array}{l}\text { Perichaena corticalis (Batsch) } \\
\text { Rostaf. }\end{array}$ & $A l$ & 2 \\
\hline $\begin{array}{l}\text { Physarum album (Bull.) } \\
\text { Chevall. }\end{array}$ & $\begin{array}{l}\text { fallen leaves of } \\
C b ; Q u ; \text { wood of } \\
\text { deciduous and } \\
\text { coniferous trees }\end{array}$ & 1; 2; 3; 4: B (30470); LŁ $(30455,30469)$ \\
\hline Ph. bivalve Pers. & fern leaves and $F s$ & 2; 4: JS (30476); W (30475) \\
\hline Ph. cinereum (Batsch) Pers. & $F s, P s$ & $2 ; 3$ \\
\hline Ph. citrinum Schumach. & $\begin{array}{l}\text { wood of deciduous } \\
\text { and coniferous trees }\end{array}$ & 4: B $(30481,30482,30483)$ \\
\hline $\begin{array}{l}\text { Ph. compressum Alb. \& } \\
\text { Schwein. }\end{array}$ & $P t$ & 1 \\
\hline Ph. globuliferum (Bull.) Pers. & Lar, $P a$ & $1 ; 2$ \\
\hline Ph. gyrosum Rostaf. & $P a, P s$ & 1 \\
\hline Ph. leucophaeum Fr. & $\begin{array}{l}\text { wood of deciduous } \\
\text { trees; Fs }\end{array}$ & 3; 4: B (30487) \\
\hline Ph. notabile T. Macbr. & Fs & 3 \\
\hline Ph.psittacinum Ditmar & stump of $Q u$ & 2 \\
\hline
\end{tabular}


Table 2 - cont.

\begin{tabular}{|c|c|c|}
\hline $\begin{array}{l}\text { Ph. robustum (Lister) Nann.- } \\
\text { Bremek. }\end{array}$ & twigs of $C a$ & 2 \\
\hline Ph. virescens Ditmar & $\begin{array}{l}Q u, \text { fallen leaves of } \\
F s ; \text { needles of } P s\end{array}$ & 2; 3; 4: B (30496, 30503); JS (30501) \\
\hline Ph. viride (Bull.) Pers. & $\begin{array}{l}\text { wood of deciduous } \\
\text { trees }\end{array}$ & 2 \\
\hline $\begin{array}{l}\text { Ph. viride var. aurantium (Bull.) } \\
\text { Lister }\end{array}$ & $\begin{array}{l}\text { wood of deciduous } \\
\text { trees; stump of } Q u\end{array}$ & 2; 4: B (30509); JS (30511) \\
\hline Reticularia lycoperdon Bull. & $\begin{array}{l}\text { wood of deciduous } \\
\text { and coniferous trees; } \\
\text { trunk of } F s ; Q u, P s\end{array}$ & 1; 2; 3; 4: LL (30515) \\
\hline $\begin{array}{l}\text { Stemonitis axifera (Bull.) T. } \\
\text { Macbr. }\end{array}$ & $\begin{array}{l}\text { wood of deciduous } \\
\text { and coniferous trees; } \\
F s, B p, Q u, P s\end{array}$ & $\begin{array}{l}\text { 1; 2; 3; 4: B (30544); LL (30531, 30534, } \\
\text { 30536, 30542); Sz (30535) }\end{array}$ \\
\hline S. flavogenita E. Jahn & $Q u$ & 2 \\
\hline S. fusca Roth & $\begin{array}{l}\text { wood of coniferous } \\
\text { trees; litter; } A l\end{array}$ & $\begin{array}{l}\text { 1; 2; 3; 4: Ba (30575); B (30561); Lubl } \\
\text { (30571) }\end{array}$ \\
\hline S. pallida Wingate & Fs & 3 \\
\hline $\begin{array}{l}\text { Stemonitopsis typhina (F.H. } \\
\text { Wigg.) Nann.-Bremek. }\end{array}$ & $\begin{array}{l}\text { wood of deciduous } \\
\text { and coniferous trees; } \\
\text { bark of } Q u ; B p, P s\end{array}$ & 1; 2; 3; 4: B (30592); JS (30712) \\
\hline Trichia affinis De Bary & Ps & 1 \\
\hline T. contorta (Ditmar) Rostaf. & $\begin{array}{l}\text { wood of deciduous } \\
\text { trees; litter }\end{array}$ & 1; 4: Msz (30597) \\
\hline T. decipiens (Pers.) T. Macbr. & $\begin{array}{l}\text { wood of deciduous } \\
\text { trees; } F s, B p\end{array}$ & $2 ; 3$ \\
\hline T. favoginea (Batsch) Pers. & $\begin{array}{l}\text { wood of deciduous } \\
\text { trees; } F s\end{array}$ & 1; 3; 4: B (30608) \\
\hline T. persimilis P. Karst. & $\begin{array}{l}\text { wood of deciduous } \\
\text { trees; } F s\end{array}$ & 2; 4: Lubl (30272) \\
\hline T. scabra Rostaf. & $B p, F s$ & 2; 3; 4: B (30614) \\
\hline $\begin{array}{l}\text { T. varia (Pers. ex J.F. Gmel.) } \\
\text { Pers. }\end{array}$ & $\begin{array}{l}\text { wood of deciduous } \\
\text { trees; Fs }\end{array}$ & 1; 2; 3; 4: Msz (30626) \\
\hline $\begin{array}{l}\text { Tubifera ferruginosa (Batsch) } \\
\text { J.F. Gmel. }\end{array}$ & $\begin{array}{l}\text { wood of deciduous } \\
\text { and coniferous trees; } \\
F s ; \text { litter; mosses }\end{array}$ & $\begin{array}{l}\text { 1; 2; 3; 4: B (30636, 30643); LE (30640, } \\
\text { 30642, 30654); S (30646, 30649) }\end{array}$ \\
\hline
\end{tabular}

Explanations. Source of information: 1 - Orzechowski (1966); 2 - Kalinowska-Kucharska (1975); 3 - Slusarczyk (2010); 4 - Herbarium material. Wood of trees: Ab - Abies alba, Al -Alnus glutinosa, Bp - Betula pendula, Ca - Corylus avellana, Cb-Carpinus betulus, Fs - Fagus sylvatica, Lar-Larix decidua, Oa - Oxalis acetosella, Qu - Quercus sp., Ps - Pinus sylvestris, Pt - Populus tremula, Tc - Tilia cordata, Vm - Vaccinium myrtillus.

2010). Several authors find beech wood as an excellent substrate for slime moulds (e.g., Miśkiewicz 2001; Stojanowska, Panek 2004). The abundance of wood in different stages of decay supports effectively development of a variety of slime moulds species (Stojanowska 1979; Drozdowicz 1992).

The results presented in the above mentioned papers as well as the studies of numerous collections from other areas of Central Poland confirm that dead wood is the most common substrate colonized by slime moulds. Even in the area of Łódź city and its surroundings decaying wood of different trees and shrubs was the basic substrate for them.

In the Tilio-Carpinetum and Potentillo albae-Quercetum, the main substrate for slime moulds was also wood (trunks, logs, stumps, twigs) and fallen leaves of Quercus and Carpinus. It corresponds with reports by other authors, e.g., Stojanowska \& Panek (2004) and Salamaga \& Drozdowicz (2010). The variety of microhabitats offering different moisture, temperature and light conditions, decide of the slime 
moulds species diversity. However, it is impossible to point the direct relationship of a particular plant association with myxomycete species composition. These observations correspond with those by other authors (e.g., Stojanowska, Panek 2002; Panek, Romański 2010). The wood of coniferous trees, especially of Pinus sylvestris needs a special attention as a substrate for slime moulds.

As the areas of occurrence of Fagus sylvatica, Abies alba and Picea abies in Central Poland are among its most valuable natural sites, and they were most thouroughly examined in terms of myxomycetes diversity, the knowledge of slime moulds in Central Poland is mainly restricted to nature reserves. There are still a lot of other places that might be rich in myxomycetes and provide interesting information about this group of organisms, like various areas of other types of forests as well as sites of anthropogenic origin. It is difficult to make any generalizations based on the data summarized in the presented checklist, but a proper programme of research focused on slime moulds collections data could bring interesting and realistic results.

\section{CONCLUSIONS}

The presented survey shows that the area of Central Poland is an attractive and valuable object of studies on myxomycetes. The results of the observations and collections that has been made for the last period of more than 50 years are an important input to the knowledge of slime moulds biodiversity. The checklist provided in the paper may serve as a source of information about the myxomycetes occurrence, species diversity, distribution and ecological relationships. It is a good starting point for further thorough qualitative and quantitative studies on slime moulds at present and in the future.

Acknowledgements. The authors would like to thank Dr. Anna Drozdowicz (Jagiellonian University) for her assistance in taxonomical interpretation of the collected materials and Dr. Marcin Kiedrzyński (University of Łódź) for preparing the map.

\section{REFERENCES}

Drozdowicz A. 1992. Slime moulds (Myxomycetes) of the Ojców National Park. III. Beech and fir logs as microhabitats of slime moulds. Zeszyty Naukowe Uniwersytetu Jagiellońskiego, Prace Botaniczne 24: $161-170$.

Drozdowicz A., Ronikier A., Stojanowska W., Panek E. 2003. Myxomycetes of Poland. A Checklist. (In:) Z. Mirek (ed.). Biodiversity of Poland. 10. W. Szafer Institute of Botany, Polish Academy of Sciences, Kraków, 103 pp.

Drozdowicz A., Ronikier A., Stojanowska W. 2006. Red list of the macrofungi in Poland. (In:) Z. Mirek, K. Zarzycki, W. Wojewoda, Z. Szeląg (eds). Red list of plants and fungi in Poland. W. Szafer Institute of Botany, Polish Academy of Sciences, Kraków: 91-99.

Heilmann-Clausen J. 2001. A gradient analysis of communities of macrofungi and slime moulds on decaying beech logs. Mycological Research 105: 575-596.

Ing B. 1994. The phytosociology of myxomycetes. New Phytologist 126: 175-201.

Ing B. 1999. The Myxomycetes of Britain and Ireland. The Richmond Publishing Co. Ltd. Slough, England. 
Kalinowska-Kucharska E. 1975. Materiały do flory śluzowców Polski Środkowej. Acta Mycol. 11 (2): 93-99.

Krieglsteiner L. 2004. Fungi in the Biosphere Reservation Rhön and their occurence in different types of vegetation. Regensb. Mykol. Schr. 12: 709-731.

Krzemieniewska H. 1960. Śluzowce Polski na tle flory śluzowców europejskich. PWN, Warszawa, 313 pp.

Lado C. 2005-2011. An on line nomenclatural information system of Eumycetozoa. http://www.nomen. eumycetozoa.com (20.08. 2011).

Ławrynowicz M. 1973. Grzyby wyższe makroskopowe w grądach Polski środkowej. Acta Mycol. 9 (2): 133-204.

Lawrynowicz M., Ślusarczyk D., Salamaga A. 2010. Myxomycetes in the Herbarium Universitatis Lodziensis (LOD F). A register of Myxomycetes from the area of Central Poland. University of Łódź, Department of Mycology (mscr).

Martin G.W., Alexopoulus C.J. 1969. The Myxomycetes. Univ. Iowa Press. Iowa City.

Mirek Z. (ed.) 2002-2009. Biodiversity of Poland. W. Szafer Institute of Botany, Polish Academy of Sciences, Kraków.

Miśkiewicz A. 2001. Slime moulds occurring in the Bukowiec reserve (W Carpathians). Acta Mycol. 36 (1): 21-29.

Nannenga-Bremekamp N. E. 1991. A Guide to Temperate Myxomycetes. Biopress Limited, Bristol.

Neubert H., Nowotny W., Baumann K., Marx H. 1993-2000. Die Myxomyceten Deutschlands und des angrenzenden Alpenraumes unter besonderer Berücksichtigung Österreichs. 1 (1993), 2 (1995), 3 (2000). Verlag Karlheinz Baumann, Gomaringen.

Orzechowski T. 1966. Śluzowce stwierdzone w okolicach Łodzi oraz w parkach łódzkich (Myxomycetes collected In the District and in the Parks of Łódź). Frag. Flor. et Geobot. 12 (2): 209-214.

Panek E., Romański M. 2010. Śluzowce Myxomycetes. (In:) L. Krzysztofiak (ed.). Śluzowce Myxomycetes, grzyby Fungi i mszaki Bryophyta Wigierskiego Parku Narodowego. Przyroda Wigierskiego Parku Narodowego, seria naukowa. Stowarzyszenie „Człowiek i Przyroda”, Suwałki: 9-85.

Salamaga A., Drozdowicz A. 2010. The myxomycetes of the Białaczów nature reserve near Opoczno. Proceed. of the $55^{\text {th }}$ meeting of the Polish Botanical Society "Planta in vivo, in vitro et in silico". Acta Societatis Botanicorum Poloniae,Warsaw: 78.

Salamaga A. 2011. The myxomycete biota of the Lagiewniki Forest in Łódź city: preliminary research results. (In:) M. Lawrynowicz, M. Ruszkiewicz-Michalska, I. Kałucka (eds). Traditional use and protection of fungi in Poland: a contribution to the Eurpean cultural heritage. Book of abstracts. Wydawnictwo Uniwersytetu Łódzkiego, Łódź: 106.

Seta D., Drozdowicz A. 2004. Nowe stanowiska śluzowców (Myxomycetes) na terenie Polski Środkowej. Streszczenia IV Ogólnopolskiego Sympozjum Mikologicznego „Grzyby w środowisku naturalnym. Metody badań terenowych", Sandomierz: 65 .

Stojanowska W. 1979. Obserwacje nad florą śluzowców butwiejącego drewna buka. Acta Mycol. 15 (1): $167-174$.

Stojanowska W., Panek E. 2002. Changes in the myxomycete biota of the „Łężczok” nature reserve near Racibórz (SW Poland). Acta Mycol. 37 (1/2): 13-28.

Stojanowska W., Panek E. 2004. Myxomycetes of the nature reserve near Wałbrzych (SW Poland). Part II. Dependence on the substrate and seasonality. Acta Mycol 39 (2): 147-159.

Śliwa L. 2010. Contribution to the lichen biota of the Pogórze Wiśnickie foothills (Carpathians). Acta Mycol. 45 (2): 219-230.

Ślusarczyk D. 2010. Some observations of slime moulds on wood and litter in beech forests. Acta Mycol. 45 (2): 239-246.

Ślusarczyk D., Ławrynowicz M., Salamaga A. 2011. Contribution to the knowledge of myxomycetes in Central Poland. (In:) M. Ławrynowicz, M. Ruszkiewicz-Michalska, I. Kałucka (eds). Traditional use and protection of fungi in Poland: a contribution to the European cultural heritage. Book of abstracts. Wydawnictwo Uniwersytetu Łódzkiego, Łódź: 130. 
Zweryfikowane dane o występowaniu śluzowców w Polsce Środkowej

\section{Streszczenie}

Kolekcja śluzowców z lat 1958-2009 z terenu Polski Środkowej przechowywana w Herbarium Uniwersytetu Łódzkiego (LOD F) była przedmiotem weryfikacji taksonomicznej z uwzględnieniem danych ekologicznych i chorologicznych. Zbiory gromadzone były z różną intensywnością, najczęściej w czasie badań mykologicznych prowadzonych na terenach leśnych, głównie w rezerwatach przyrody chroniących stanowiska jodły, buka i świerka na granicy występowania tych drzew w Polsce.

Na podstawie analizy 750 eksykatów zidentyfikowano 81 taksonów śluzowców. Materiał pochodził z 34 stanowisk reprezentujących szerokie zróżnicowanie siedliska od rezerwatów przyrody do skrajnie zmienionych terenów w warunkach miejskich i podmiejskich Łodzi. Podsumowanie wyników zawiera krytyczna lista śluzowców Polski Środkowej.

Obecnie, w związku z podejmowaniem szczegółowych badań nad śluzowcami tego terenu, stanowić może punkt wyjścia do badań nad bioróżnorodnością, ekologią i rozmieszczeniem śluzowców Polski Środkowej oraz służyć do porównania z innymi obszarami obecnie i w przyszłości. 